\title{
Water quality in Cidurian watershed, Indonesia
}

\author{
Rahmah Dewi Yustika*, and Ratri Ariani \\ Indonesian Soil Research Institute, Jl. Tentara Pelajar 12, Bogor, Indonesia
}

\begin{abstract}
Studies about river water quality are essential since the decreasing of water quality could threaten hydrology watershed function. The objective of this study was to identify water quality in rainy and dry seasons of Cidurian watershed. Water quality data were obtained from Main River Basin Organization Territory Cidanau - Ciujung - Cidurian for 2018 and 2019. The parameters of water quality consist of total suspended solids (TSS), $\mathrm{pH}$, dissolved oxygen (DO), chemical oxygen demand (COD), biochemical oxygen demand (BOD), phosphate $\left(\mathrm{PO}_{4}\right)$, nitrite $\left(\mathrm{NO}_{2}-\mathrm{N}\right)$, electrical conductivity (EC), temperature, $\mathrm{Ca}$, and $\mathrm{Mg}$. Water sampling location were in Jasinga (upstream), Neglasari (middle stream), Rancasumur (middle stream), and Tanara (downstream). The result showed that TSS concentration showed higher in rainy season than dry season in all sampling points with values higher than river water quality standard $50 \mathrm{mg} / \mathrm{L}$. Therefore, need attention to adopt soil conservation practices in mixed tree crops, dry cultivation land, and crop plantation to decrease soil erosion. Downstream had values of $\mathrm{pH}, \mathrm{DO}$, COD, and BOD outside of water quality standards. Accordingly, government should issue some policies to protect from decreasing water quality. The information on river water quality in Cidurian watershed could support better watershed management for sustainable hydrology watershed function.
\end{abstract}

\section{Introduction}

The river water condition is determined by the relationship between climate, anthropogenic activities and natural processes [1]. Land use change as a result of human activities, urban development, and industry has impacts on high surface runoff and floods [2,3]. Cidurian watershed, as a rapidly developing area related human activities, needs concern for its future as a drinking water source, irrigation, and supporting domestic purposes. Kusumo and Nursari [4] stated that middle and downstream of the Cidurian watershed prone to flood occurrence.

Adoption land management could decline discharge flow and hence minimize flood and sedimentation. Simulation by Ismoyo and Mardyanto [5] found that application dam in Cidurian upstream could decline flood $16 \%$. Watershed management is necessary due to various activities such as agriculture, residential, industry, and plantation impacts on river water quality. Understanding the interaction between various activities and watershed

\footnotetext{
* Corresponding author: $\underline{\text { rd yustika@yahoo.com }}$
} 
characteristics provides a base for environmental management to maintain the functioning of the hydrologic watershed.

Seasonal precipitation had effects on surface runoff and hence influence flow discharges and contaminants in the stream water [6,7]. Therefore, need comprehensive planning to minimize the negative impacts of activities that decrease water quality. Studies about the relationship between watershed characteristics and seasonal precipitation during rainy and dry seasons support watershed management. The objective of this study was to identify water quality in seasonal variability in Cidurian watershed. Water qualities, from upstream to downstream watershed, were identified to understand its characteristics. Further, information of water quality support watershed management for sustainable hydrology watershed function.

\section{Materials and method}

\subsection{Study area description}

The study area was in the Cidurian watershed, where administrative locations belong to Banten and West Java Provinces of Indonesia (Fig. 1). The geographic coordinate position of the study area was at $106^{\circ} 18^{\prime} 00^{\prime \prime} \mathrm{E}$ to $106^{\circ} 34^{\prime} 00^{\prime \prime} \mathrm{E}$ and $6^{\circ} 00^{\prime} 00^{\prime \prime} \mathrm{S}$ to $06^{\circ} 48^{\prime} 00^{\prime \prime} \mathrm{S}$. The total area of study location was $844.96 \mathrm{~km}^{2}$. Cidurian watershed consists of $6 \mathrm{sub}-$ watersheds. Sub-watersheds located in the upstream area were Cidurian Hulu and Cipangaur sub-watersheds. Cibeureum and Cilalay sub-watersheds were in the middle stream, while Cikande and Cidurian Hilir sub-watersheds in downstream.

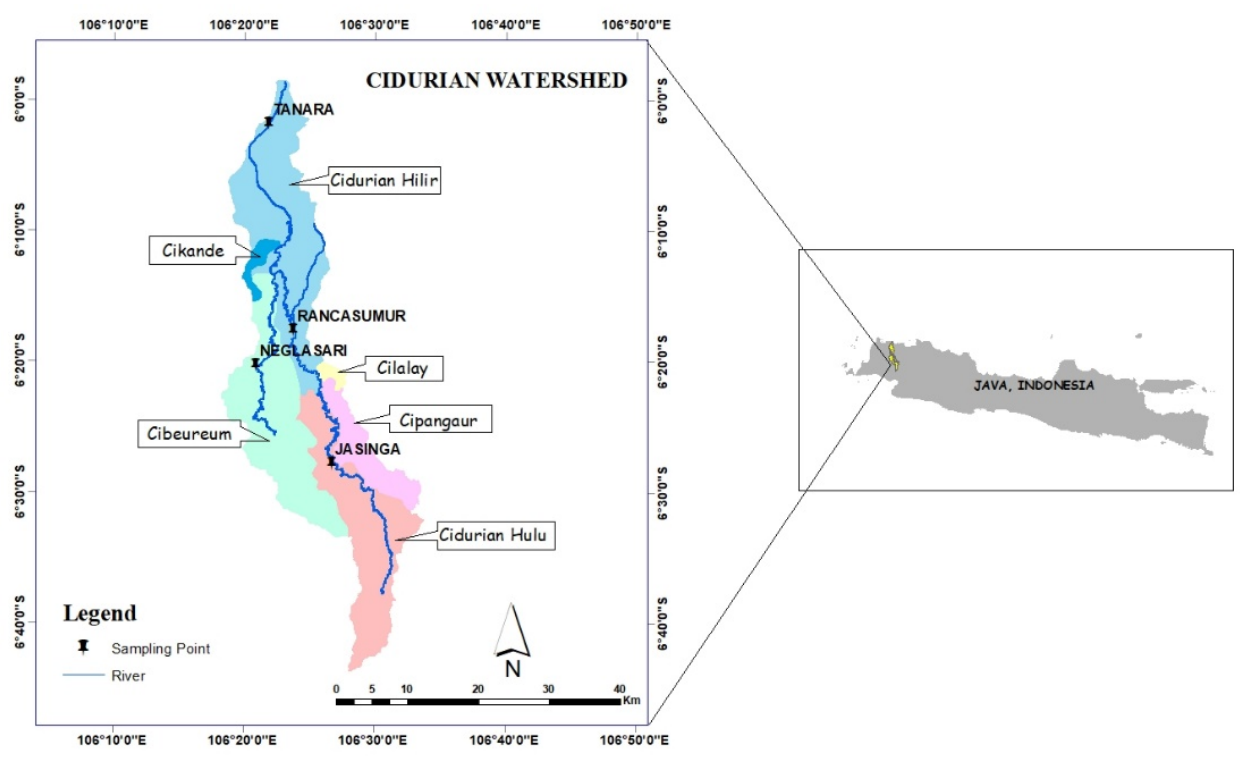

Fig. 1. Location of the study area

Land use composition in Cidurian watershed presented in Table 1. The main land use in Cidurian Hulu, Cipangaur, Cibeureum, and Cilalay sub-watersheds were mixed tree crops. Next, land use dominants in Cikande and Cidurian Hilir sub-watersheds (downstream) were rice fields. 
Table 1. Land use of Cidurian watershed

\begin{tabular}{|l|l|l|l|l|l|l|}
\hline \multirow{2}{*}{ Land use } & \multicolumn{7}{|c|}{ Sub-watershed (ha) } \\
\cline { 2 - 8 } & $\begin{array}{c}\text { Cidurian } \\
\text { Hulu }\end{array}$ & Cipangaur & Cibeureum & Cilalay & Cikande & $\begin{array}{c}\text { Cidurian } \\
\text { Hilir }\end{array}$ \\
\hline Water Bodies & 112.77 & 6.62 & & & 29.11 & 1.93 \\
\hline Mixed Tree Crop & $10,909.68$ & $2,497.77$ & $15,748.68$ & 464.36 & & 337.48 \\
\hline Dry Cultivation Land & $1,703.67$ & $1,127.45$ & $1,478.18$ & 222.34 & 290.11 & 644.71 \\
\hline Rice Field & $3,550.54$ & 427.24 & $3,498.46$ & 103.89 & 916.71 & $23,093.67$ \\
\hline Bare Land & 6.74 & 117.19 & 54.26 & 58.72 & & \\
\hline Mining & & 25.56 & & & & \\
\hline Plantation Forest & 471.96 & $1,104.45$ & 179.42 & 123.02 & & \\
\hline Secondary Forest & $2,854.65$ & $1,334.37$ & 261.47 & & & \\
\hline Crop Plantation & $1,552.16$ & 608.78 & $1,690.96$ & & & \\
\hline Settlements & 944.96 & 230.99 & 972.64 & 18.55 & 417.06 & $2,834.85$ \\
\hline Coastal Fishpond & & & & & & $1,433.07$ \\
\hline Airport/Port & & & & & & 35,04 \\
\hline Total & $22,107.13$ & $7,480.42$ & $23,884.05$ & 990.88 & $1,652.99$ & $23,380.75$ \\
\hline
\end{tabular}

\subsection{Water quality data}

Water quality data were obtained from Main River Basin Organization Territory Cidanau Ciujung - Cidurian [8,9] for 2018 and 2019. Water quality parameters consist of total suspended solids (TSS), pH, dissolved oxygen (DO), chemical oxygen demand (COD), biochemical oxygen demand (BOD), phosphate $\left(\mathrm{PO}_{4}\right)$, nitrite $\left(\mathrm{NO}_{2}-\mathrm{N}\right)$, electrical conductivity (EC), temperature, $\mathrm{Ca}$, and $\mathrm{Mg}$. The data was taken in Jasinga (Cidurian Hulu, upstream), Neglasari (Cibeureum, middle stream), and Tanara (Cidurian Hilir, downstream, Fig. 1). Also, the data had taken in the Rancasumur sampling point. Rancasumur was represented as the middle stream point of the whole Cidurian watershed due to Rancasumur had located in the upper area of the Cidurian Hilir sub-watershed.

The water quality data were collected once a month in 2018 and 2019, except phosphate, which was collected only in 2019. The water quality parameters were analyses through Standar Nasional Indonesia (SNI, Indonesian National Standard) methods. Analyses of water quality was conducted in the laboratory under Main River Basin Organization Territory Cidanau - Ciujung - Cidurian.

Water quality data analyses seasonally in rainy and dry seasons. Precipitation data was obtained from Main River Basin Organization Territory Cidanau - Ciujung - Cidurian [10]. Precipitation data for 2018 was collected from the precipitation stations of Cikasungka, Cisalak Baru, Rancasumur, and Toge. Besides, data for 2019 was collected from precipitation stations of Cinta, Cisalak Baru, Pamanuk Carenang, and Rancasumur (Fig. 2). The determination of the rainy season was decided by three times of decadal (10 days) in sequence, and each had a rainfall of more than $50 \mathrm{~mm}$. Conversely, the dry season was categorized if three times of decadal in sequence each had rainfall less than $50 \mathrm{~mm}$ [11]. Based on precipitation data in 2018, the rainy season was in January - June and October December, while the dry season was in July - September. In 2019, the rainy season was in January - May and December, while the dry season was in June - November. 


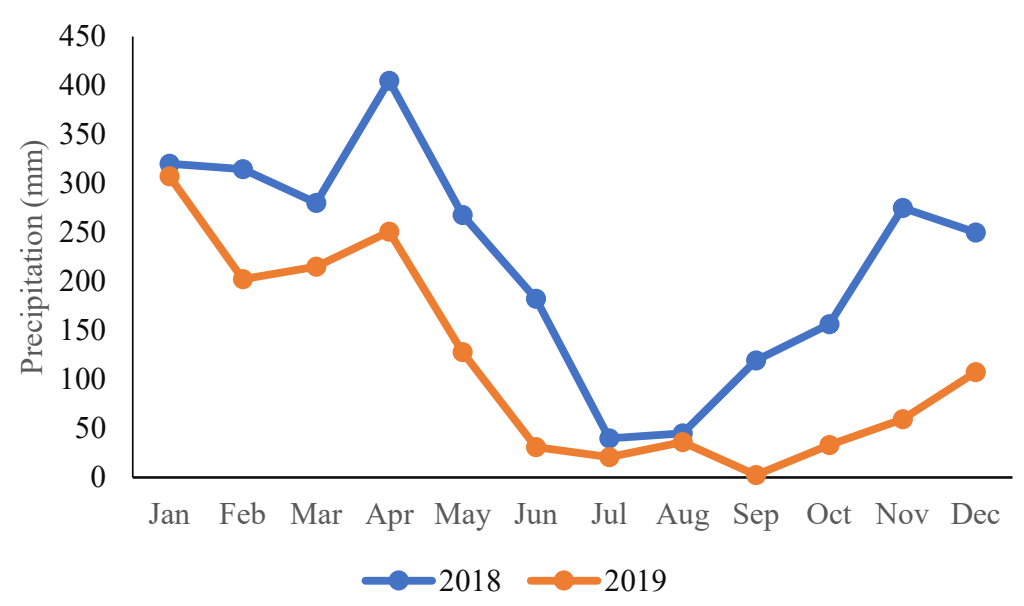

Fig. 2. Precipitation in Cidurian watershed

\subsection{Statistical analysis}

The normality water quality data was examined by Kolmogorov-Smirnov. A logtransformed data was needed in this analysis. Normal distribution data during rainy and dry seasons in different water sampling points was performed through a one-way analysis of variance test (ANOVA) and continued with the Duncan test. Non-normal distribution data were analyzed by the Kruskal Wallis test, followed by the Dunn test. Identifying the trend of each water quality parameter during rainy and dry seasons in a location was analyzed using Independent T-test for normal distribution and Mann Whitney test for non-normal distribution. All the statistical analyses were conducted by IBM SPSS Statistics 26.

\section{Result and discussion}

\subsection{Water quality concentration}

Water quality concentration of TSS, $\mathrm{pH}, \mathrm{DO}$, nitrite, phosphate, temperature, $\mathrm{Ca}$, and $\mathrm{Mg}$ in Jasinga, Rancasumur, Neglasari, and Tanara did not show significant differences during the rainy season (Fig. 3) while COD, BOD, and EC concentration presented a significantly different value among sampling locations during the rainy season. The concentration of TSS, COD, phosphate, and EC during the dry season showed significantly different in four locations of water sampling points (Fig.4).

TSS concentration was higher value during rainy season than dry season in all sampling points (Table 2). The order of TSS concentration from the highest to the lowest in rainy season was Neglasari $(207.19 \pm 309.11 \mathrm{mg} / \mathrm{L})$, Tanara $(176.71 \pm 51 \mathrm{mg} / \mathrm{L})$, Jasinga (154.34 $\pm 74.38 \mathrm{mg} / \mathrm{L})$, and Rancasumur (144.84 $\pm 72.60 \mathrm{mg} / \mathrm{L})$. The highest TSS concentration in dry season was Tanara $(134.63 \pm 61.35 \mathrm{mg} / \mathrm{L})$, then followed by Jasinga $(106.40 \pm 45.77$ $\mathrm{mg} / \mathrm{L})$, Neglasari $(91.12 \pm 36 \mathrm{mg} / \mathrm{L})$, and Rancasumur $(85.66 \pm 37.19 \mathrm{mg} / \mathrm{L})$. Research in Rwanda stated that TSS concentration was higher during high precipitation [12] because soil particle will easily be dispersed by rain splash and transported to stream water. The condition of Cibeureum sub-watershed, where water sampling point Neglasari located, had dominant land use mixed tree crop which covered $65.94 \%$ of total area Cibeureum subwatershed. Besides, Cibeureum sub-watershed consist of dry cultivation land $16.9 \%$ and 
crop plantation $7.08 \%$. Lack of attention to land conservation management could increase soil erosion in agricultural land. Soil erosion resulted in decreasing water quality because of sedimentation pollutants in stream water. Research in Lampung revealed that higher TSS concentration resulted from soil erosion [13] of young coffee plantations whose less canopy cover. The high concentration of TSS in Tanara (downstream) is probably because as the accumulation of waste from upstream and middle stream. In addition, Tanara had high settlements area that could affect TSS concentration.

Concentration of $\mathrm{pH}$ in all sampling locations indicated higher in dry season than rainy season except in Tanara (Table 2). The photosynthesis process increase $\mathrm{pH}$ value during dry season [12]. $\mathrm{pH}$ values in Jasinga, Neglasari, Rancasumur, and Tanara during dry season ranged from $6.74-7.80,6.6-7.55,6.82-7.48$, and $5.45-7.68$, respectively. Furthermore, $\mathrm{pH}$ in Jasinga, Neglasari, Rancasumur, and Tanara during rainy season ranged $6.54-7.70,6.34-7.48,6.21-7.87$, and $6.10-7.45$, respectively.

Concerning DO concentration, the values did not significantly differ between seasons (Table 2). The trend of average DO concentration indicated higher during rainy season compares to dry season in Rancasumur, Neglasari, and Tanara, while average DO concentration indicated higher during dry season than rainy season in Jasinga. Minimum values during rainy and dry seasons in all sampling points was below $4 \mathrm{mg} / \mathrm{L}$. DO is the amount of oxygen available in the water. Lower DO in dry season related to intensive microorganism activity need oxygen for organic matter degradation and metabolic process [14]. Besides, the DO got the influence from anthropogenic inputs preventing oxygen dissolution during low discharge phase [15].

COD concentration in Jasinga, Rancasumur, and Neglasari had higher concentrations in rainy season than dry season, while COD concentration in Tanara had a higher concentration in dry season than rainy season. The sampling point in Neglasari (middle stream) presented a significantly higher COD value in rainy season than dry season. In addition, Tanara (downstream) had the highest value of COD average during rainy (20.93 \pm $7.83 \mathrm{mg} / \mathrm{L})$ and dry $(27.98 \pm 10.77 \mathrm{mg} / \mathrm{L})$ seasons than other sampling locations. Barakat et al., [16] revealed that COD concentration had connected with leaching process, agricultural pollutant, domestic sewage, and industrial pollutant. The higher COD in rainy season than dry season in Jasinga, Rancasumur, and Neglasari is related to agricultural pollutants as these places are located in sub-watersheds that had agricultural land consist of the mixed tree crop, crop plantation, and dry cultivation land. Higher precipitation in rainy season will transport agricultural pollutants to stream water. Downstream areas, Tanara, have the largest concentration of COD for both rainy and dry seasons, which indicated waste concentration [17] coming from settlements.

BOD is a water quality parameter for indicating biodegradable organic substances. BOD concentration indicated higher during dry season than rainy season in Jasinga, Neglasari, and Tanara (Table 2). Condition in Rancasumur indicated a different trend that had higher BOD concentration during rainy season. Further, the BOD value of Jasinga in dry season showed significantly larger in dry season $(1.92 \mathrm{mg} / \mathrm{L})$ than rainy season $(1.15 \mathrm{mg} / \mathrm{L})$, while others did not show significant differences between the two seasons. During dry season, BOD levels indicate have higher concentration because of low water flow and increase of residential wastewater [18]. Tanara showed the highest concentration during rainy $(2.03 \pm$ $0.97 \mathrm{mg} / \mathrm{L})$ and dry $(5.35 \pm 7.14 \mathrm{mg} / \mathrm{L})$ seasons compares to other locations as downstream have more urban waste [19]. 


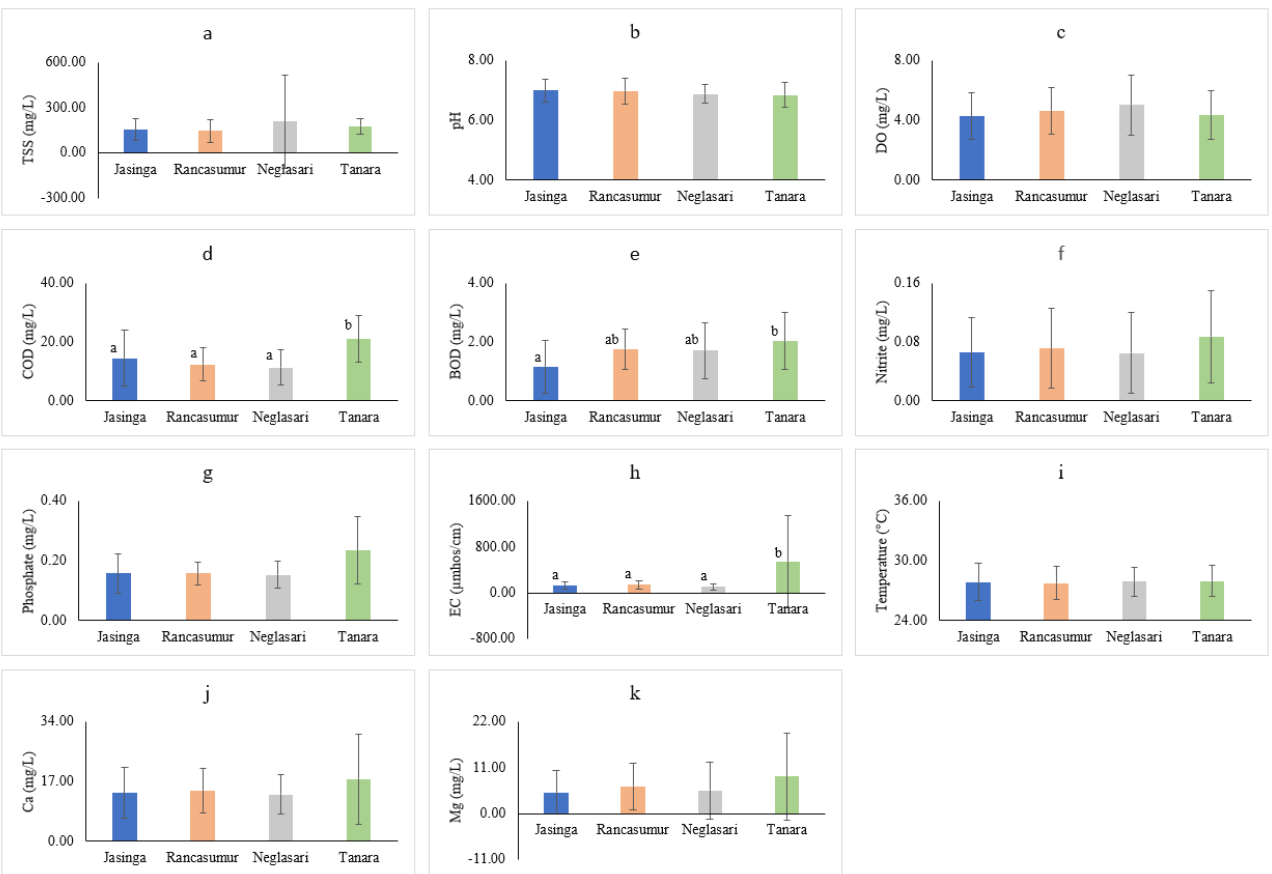

Fig. 3. Water quality concentration in rainy season in Jasinga, Rancasumur, Neglasari, and Tanara
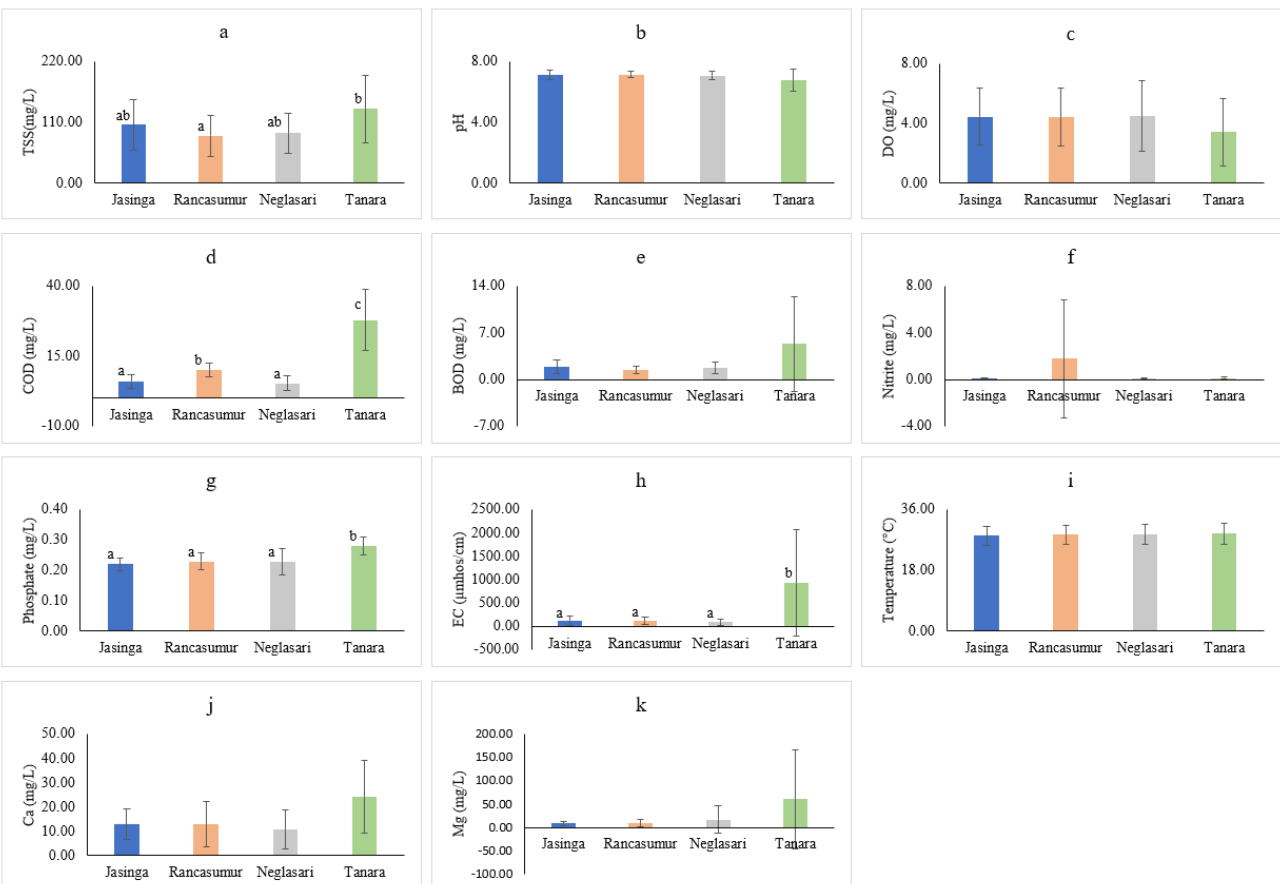

Fig. 4. Water quality concentration in dry season in Jasinga, Rancasumur, Neglasari, and Tanara 
Table 2. Water quality concentration in rainy season and dry season

\begin{tabular}{|c|c|c|c|c|c|c|c|c|c|c|c|c|c|c|c|c|c|}
\hline \multirow{2}{*}{$\begin{array}{l}\text { Para- } \\
\text { meter }\end{array}$} & \multirow{2}{*}{$\begin{array}{c}\text { Seas } \\
\text { on }\end{array}$} & \multicolumn{4}{|c|}{ Jasinga } & \multicolumn{4}{|c|}{ Rancasumur } & \multicolumn{4}{|c|}{ Neglasari } & \multicolumn{4}{|c|}{ Tanara } \\
\hline & & $\mathrm{N}$ & Min & Max & $\begin{array}{l}\text { Mean } \pm \\
\text { Std Dev }\end{array}$ & $\mathrm{N}$ & Min & Max & $\begin{array}{l}\text { Mean } \pm \\
\text { Std Dev }\end{array}$ & $\mathrm{N}$ & Min & $\operatorname{Max}$ & $\begin{array}{l}\text { Mean } \pm \\
\text { Std Dev }\end{array}$ & $\mathrm{N}$ & Min & Max & $\begin{array}{l}\text { Mean } \pm \\
\text { Std Dev }\end{array}$ \\
\hline \multirow[t]{2}{*}{$\begin{array}{c}\text { TSS } \\
(\mathrm{mg} / \mathrm{L})\end{array}$} & RS & 15 & 61.5 & 306.5 & $\begin{array}{c}154.34 \\
\pm 74.38 \\
\end{array}$ & 15 & 15.5 & 290 & $\begin{array}{l}144.84^{*} \\
\pm 72.60 \\
\end{array}$ & 15 & 59 & 1321 & $\begin{array}{r}207.19^{*} \\
\pm 309.11 \\
\end{array}$ & 14 & 72 & 250 & $\begin{array}{c}176.71 \pm \\
51\end{array}$ \\
\hline & DS & 8 & 65.81 & 174.86 & $\begin{array}{l}106.40 \\
\pm 45.77 \\
\end{array}$ & 9 & 40.37 & 132.12 & $\begin{array}{c}85.66 \pm \\
37.19\end{array}$ & 9 & 35 & 140 & $\begin{array}{c}91.12 \pm \\
36.2\end{array}$ & 9 & 65.4 & 221.65 & $\begin{array}{c}134.63 \pm \\
61.35\end{array}$ \\
\hline \multirow[t]{2}{*}{$\mathrm{pH}$} & RS & 15 & 6.54 & 7.7 & $\begin{array}{c}7.01 \pm \\
0.38 \\
\end{array}$ & 15 & 6.21 & 7.87 & $\begin{array}{c}6.98 \pm \\
0.43 \\
\end{array}$ & 15 & 6.34 & 7.48 & $\begin{array}{c}6.89 \pm \\
0.32 \\
\end{array}$ & 14 & 6.1 & 7.45 & $\begin{array}{c}6.86 \pm \\
0.4 \\
\end{array}$ \\
\hline & DS & 9 & 6.74 & 7.8 & $\begin{array}{c}7.14 \pm \\
0.32\end{array}$ & 9 & 6.82 & 7.48 & $\begin{array}{c}7.18 \pm \\
0.22\end{array}$ & 9 & 6.6 & 7.55 & $\begin{array}{c}7.10 \pm \\
0.30\end{array}$ & 9 & 5.45 & 7.68 & $\begin{array}{c}6.79 \pm \\
0.73\end{array}$ \\
\hline \multirow[t]{2}{*}{$\begin{array}{c}\mathrm{DO} \\
(\mathrm{mg} / \mathrm{L})\end{array}$} & RS & 15 & 2.21 & 8.66 & $\begin{array}{c}4.27 \pm \\
1.56\end{array}$ & 15 & 2.01 & 7.85 & $\begin{array}{c}4.65 \pm \\
1.55\end{array}$ & 15 & 3.02 & 9.87 & $\begin{array}{c}5.03 \pm \\
2.01\end{array}$ & 14 & 2.62 & 8.86 & $\begin{array}{c}4.36 \pm \\
1.63\end{array}$ \\
\hline & DS & 9 & 1.18 & 7.45 & $\begin{array}{c}4.45 \pm \\
1.90 \\
\end{array}$ & 9 & 1.57 & 7.85 & $\begin{array}{c}4.39 \pm \\
1.93 \\
\end{array}$ & 9 & 1.57 & 9.56 & $\begin{array}{c}4.46 \pm \\
2.36 \\
\end{array}$ & 9 & 0.4 & 7.75 & $\begin{array}{c}3.4 \pm \\
2.26 \\
\end{array}$ \\
\hline \multirow[t]{2}{*}{$\begin{array}{c}\mathrm{COD} \\
(\mathrm{mg} / \mathrm{L})\end{array}$} & RS & 15 & 1.98 & 29.64 & $\begin{array}{c}14.45 \pm \\
9.46\end{array}$ & 15 & 3.95 & 23.71 & $\begin{array}{c}12.40 \pm \\
5.74 \\
\end{array}$ & 15 & 3.98 & 21.74 & $\begin{array}{c}11.33^{* *} \pm \\
5.86\end{array}$ & 14 & 13.83 & 43.47 & $\begin{array}{c}20.93 \pm \\
7.83 \\
\end{array}$ \\
\hline & DS & 9 & 1.98 & 9.2 & $\begin{array}{c}6.00 \pm \\
2.38 \\
\end{array}$ & 9 & 7.23 & 14.98 & $\begin{array}{c}10.12 \pm \\
2.45 \\
\end{array}$ & 9 & 1.98 & 8.91 & $\begin{array}{l}5.3 \pm \\
2.55 \\
\end{array}$ & 9 & 11.23 & 45.45 & $\begin{array}{c}27.98 \pm \\
10.77 \\
\end{array}$ \\
\hline \multirow[t]{2}{*}{$\begin{array}{c}\mathrm{BOD} \\
(\mathrm{mg} / \mathrm{L})\end{array}$} & RS & 15 & 0.2 & 2.62 & $\begin{array}{c}1.15 \pm \\
0.90\end{array}$ & 15 & 0.81 & 3.22 & $\begin{array}{c}1.75 \pm \\
0.70 \\
\end{array}$ & 15 & 0.2 & 3.42 & $\begin{array}{c}1.71 \pm \\
0.95\end{array}$ & 13 & 0.6 & 3.42 & $\begin{array}{c}2.03 \pm \\
0.97\end{array}$ \\
\hline & DS & 9 & 0.4 & 3.22 & $\begin{array}{c}1.92^{*} \pm \\
1.10\end{array}$ & 9 & 0.87 & 2.42 & $\begin{array}{c}1.41 \pm \\
0.56\end{array}$ & 9 & 0.97 & 3.22 & $\begin{array}{c}1.79 \pm \\
0.88\end{array}$ & 9 & 0.6 & 20.13 & $\begin{array}{c}5.35 \pm \\
7.14\end{array}$ \\
\hline \multirow[t]{2}{*}{$\begin{array}{l}\begin{array}{l}\text { Nitrite } \\
\text { (mg/L) }\end{array} \\
\end{array}$} & RS & 14 & 0.01 & 0.14 & $\begin{array}{c}0.07 \pm \\
0.05\end{array}$ & 14 & 0.02 & 0.15 & $\begin{array}{c}0.07 \pm \\
0.05\end{array}$ & 14 & 0.02 & 0.14 & $\begin{array}{c}0.07 \pm \\
0.06\end{array}$ & 13 & 0.02 & 0.17 & $\begin{array}{c}0.09 \pm \\
0.06\end{array}$ \\
\hline & DS & 9 & 0.01 & 0.17 & $\begin{array}{c}0.10 \pm \\
0.06 \\
\end{array}$ & 9 & 0.01 & 15.26 & $\begin{array}{c}1.78 \pm \\
5.06\end{array}$ & 9 & 0.01 & 0.15 & $\begin{array}{l}0.1 \pm \\
0.06 \\
\end{array}$ & 9 & 0.01 & 0.28 & $\begin{array}{c}0.12 \pm \\
0.09 \\
\end{array}$ \\
\hline \multirow[t]{2}{*}{$\begin{array}{c}\text { Phosphate } \\
\text { (mg/L) }\end{array}$} & RS & 4 & 0.09 & 0.25 & $\begin{array}{c}0.16 \pm \\
0.07\end{array}$ & 4 & 0.12 & 0.21 & $\begin{array}{c}0.16 \pm \\
0.04\end{array}$ & 4 & 0.1 & 0.21 & $\begin{array}{c}0.15 \pm \\
0.05 \\
\end{array}$ & 4 & 0.16 & 0.4 & $\begin{array}{c}0.24 \pm \\
0.11 \\
\end{array}$ \\
\hline & DS & 6 & 0.2 & 0.25 & $\begin{array}{c}0.22 \pm \\
0.02\end{array}$ & 6 & 0.18 & 0.26 & $\begin{array}{c}0.23^{\star} \pm \\
0.03\end{array}$ & 6 & 0.15 & 0.28 & $\begin{array}{c}0.23^{*} \pm \\
0.04\end{array}$ & 6 & 0.24 & 0.33 & $\begin{array}{c}0.28 \pm \\
0.03\end{array}$ \\
\hline \multirow[t]{2}{*}{$\begin{array}{c}E C \\
(\mu \mathrm{mhos} / \mathrm{cm})\end{array}$} & RS & 15 & 56.72 & 235 & $\begin{array}{r}125.30 \\
\pm 63.06 \\
\end{array}$ & 15 & 78 & 281.26 & $\begin{array}{c}141.18 \pm \\
71.57\end{array}$ & 15 & 43.4 & 200.11 & $\begin{array}{c}102.32 \pm \\
47.36 \\
\end{array}$ & 14 & 101.5 & 2100 & $\begin{array}{c}551.77 \pm \\
804.52 \\
\end{array}$ \\
\hline & DS & 9 & 34.5 & 261.23 & $\begin{array}{c}121.76 \\
\pm 99.90 \\
\end{array}$ & 9 & 45.1 & 265 & $\begin{array}{c}114.35 \pm \\
85.32\end{array}$ & 9 & 31.6 & 223 & $\begin{array}{c}91.68 \pm \\
68.61 \\
\end{array}$ & 9 & 96.8 & 3610 & $\begin{array}{l}922.46 \pm \\
1141.32 \\
\end{array}$ \\
\hline
\end{tabular}




\begin{tabular}{|c|c|c|c|c|c|c|c|c|c|c|c|c|c|c|c|c|c|c|}
\hline $\begin{array}{c}\text { Tempe- } \\
\text { rature }\left({ }^{\circ} \mathrm{C}\right)\end{array}$ & RS & 15 & 25 & 32 & $\begin{array}{c}27.85 \pm \\
1.88\end{array}$ & 15 & 25 & 32 & $\begin{array}{c}27.77 \pm \\
1.71\end{array}$ & 15 & 25 & 31.7 & $\begin{array}{c}27.91 \pm \\
1.47\end{array}$ & $\begin{array}{c}14 \\
25\end{array}$ & 31.8 & $\begin{array}{c}27.99 \pm \\
1.56\end{array}$ \\
\hline & DS & 9 & 23.4 & 31.8 & $\begin{array}{c}28.26 \pm \\
2.86\end{array}$ & 9 & 24.4 & 32.2 & $\begin{array}{c}28.59 \pm \\
2.81\end{array}$ & 9 & 23.5 & 32.4 & $\begin{array}{c}28.67 \pm \\
3.09\end{array}$ & 9 & 23.4 & 32.1 & $\begin{array}{c}28.87 \pm \\
3.14\end{array}$ \\
\hline $\mathrm{Ca}(\mathrm{mg} / \mathrm{L})$ & $\mathrm{RS}$ & 15 & 3.12 & 32 & $\begin{array}{c}13.70 \pm \\
7.22\end{array}$ & 15 & 3.2 & 27.2 & $\begin{array}{c}14.54 \pm \\
6.35\end{array}$ & 15 & 6.4 & 25.6 & $\begin{array}{c}13.36 \pm \\
5.70\end{array}$ & $\begin{array}{c}14 \\
14\end{array}$ & 8 & 54.4 & $\begin{array}{c}17.68 \pm \\
12.91\end{array}$ \\
\hline & DS & 9 & 3.36 & 22.4 & $\begin{array}{c}12.77 \pm \\
6.35\end{array}$ & 9 & 3.68 & 25.6 & $\begin{array}{c}12.95 \pm \\
9.30\end{array}$ & 9 & 3.52 & 25.6 & $\begin{array}{c}10.80 \pm \\
7.96\end{array}$ & 9 & 4.16 & 52.8 & $\begin{array}{c}24.21 \pm \\
15.17\end{array}$ \\
\hline $\mathrm{Mg}(\mathrm{mg} / \mathrm{L})$ & RS & 15 & 0.97 & 20.4 & $\begin{array}{c}5.05 \pm \\
5.20\end{array}$ & 15 & 0.97 & 18.04 & $\begin{array}{c}6.52 \pm \\
5.62\end{array}$ & 14 & 0.97 & 24.85 & $\begin{array}{c}5.59 \pm \\
6.83\end{array}$ & $\begin{array}{c}14 \\
14\end{array}$ & $\begin{array}{c}1.94 \\
4.93\end{array}$ & 43.92 & $\begin{array}{c}8.86 \pm \\
10.39\end{array}$ \\
\hline & DS & 9 & 2.92 & 14.2 & $\begin{array}{c}8.37 \pm \\
3.98\end{array}$ & 9 & 3.4 & 27.73 & $\begin{array}{c}9.20 \pm \\
7.85\end{array}$ & 9 & 0.97 & 92 & $\begin{array}{c}17.08 \pm \\
28.60\end{array}$ & 9 & 3.89 & 282 & $\begin{array}{c}60.37 \pm \\
105.72\end{array}$ \\
\hline
\end{tabular}

Rainy Season (RS), Dry Season (DS) 
Concentration of nitrite, phosphate, temperature, and $\mathrm{Mg}$ presented higher trends during dry season than rainy season in all sampling points. Lower level of phosphate, nitrite, and $\mathrm{Mg}$ in rainy season is most likely a result of dilution effect. High phosphate concentration during dry season because of low discharge [20]. Phosphate concentration in Rancasumur and Neglasari performed significantly higher during dry season than rainy season.

$\mathrm{EC}$ and $\mathrm{Ca}$ concentrations were higher during rainy season than dry season in sampling points of upper and middle streams except for downstream (Tanara). Tanara showed the highest concentration of EC $(551.77 \pm 804.52)$ and $\mathrm{Ca}(17.68 \pm 12.91 \mathrm{~m} / \mathrm{L})$ during rainy season compares other locations. In addition, Tanara had higher trend of EC (922.46 \pm $1141.32)$ and $\mathrm{Ca}(24.21 \pm 15.17 \mathrm{mg} / \mathrm{L})$ during dry season. Values of EC and $\mathrm{Ca}$ in the upstream and middle stream were influenced by agricultural land use, especially in rainy season. Ngoye and Machiwa [21] stated that agricultural areas related to EC values. High EC in downstream during dry season related to evaporation of electrolyte [17] from settlement's waste. Furthermore, EC concentration got effects from waste concentration from upstream and middle stream.

\subsection{Water quality status}

The values of TSS during rainy and dry season in all sampling locations were higher than standard $50 \mathrm{mg} / \mathrm{L}$ of class 2 for recreation, irrigation, livestock, freshwater fish farming [22]. Sampling point Neglasari had the highest TSS concentration $(207.19 \pm 309.11 \mathrm{mg} / \mathrm{L})$ in rainy season needs more attention to reduce soil erosion (Table 2). Adopting soil conservation techniques such as contour cropping, terracing, and cover cropping could reduce soil erosion [23,24,25] in mixed tree crop, dry cultivation farming, and crop plantation. Furthermore, these soil managements also could decrease nutrient transport to stream water.

Tanara which is located in downstream (Cibeureum Hilir sub - watershed) had some issue of lower water quality than in upstream (Jasinga) and middle streams (Rancasumur and Neglasari). Some values of $\mathrm{pH}, \mathrm{DO}, \mathrm{COD}$, and BOD (Table 2) were outside of class 2 of river water quality standards based on Regulation Government of Republic Indonesia No.2/2021 [22]. Minimum $\mathrm{pH}$ value in Tanara 5.45 was lower than water quality standard $\mathrm{pH} 6-9$. DO concentration in Tanara showed the lowest averages of $3.4 \pm 2.26 \mathrm{mg} / \mathrm{L}$ in dry season, which this value lower than water quality standard minimum $4 \mathrm{mg} / \mathrm{L}$. In addition, other sampling locations also had minimum values lower than $4 \mathrm{mg} / \mathrm{L}$. Maximum COD data in rainy and dry seasons of Tanara showed exceeded values than standard of a maximum $25 \mathrm{mg} / \mathrm{L}$. Besides, the average of COD in dry season was $27.98 \pm 10.77 \mathrm{mg} / \mathrm{L}$. BOD value in Tanara in dry season was $5.35 \pm 7.14 \mathrm{mg} / \mathrm{L}$ which showed higher than river water quality standard maximum of $3 \mathrm{mg} / \mathrm{L}$. Tanara had the highest urban area (settlements land use) than other sub-watersheds, which resulted in pollution. Besides, Tanara also received pollution from above upstream and middle streams. Therefore, need attention from government to concern about some parameters with values beyond the water quality standard. Government policies are important to protect river water from decreasing quality as river water support ecosystem. Moreover, wastewater management is necessary to overcome lowering water quality.

\section{Conclusion}

Water quality in Cidurian watershed presented spatial and seasonal variations. Climatic variability influence relationship between water quality and land use pattern. To overcome 
higher concentration of TSS needs application of soil conservation practices to reduce soil erosion, especially in upper and middle stream areas. Lower of water qualities of $\mathrm{pH}, \mathrm{DO}$, $\mathrm{COD}$, and BOD in downstream areas need attention from government to concern about wastewater management. Study water quality is helpful for understand water quality manner within watershed scale. The findings from this study give information to policymakers and watershed managers to provide management strategies. Furthermore, monitoring water pollution within the watershed is necessary to regulate a sustainable environment and support hydrology watershed function.

\section{References}

1. R.D. Yustika, H. Somura, S.B. Yuwono, T. Masunaga, Water. 11, 2363 (2019)

2. P. Shi, Y. Zhang, Z. Li, P. Li, G. Xu, Catena. 151, 182-190 (2017)

3. H. El Kateb, H. Zhang, P. Zhang, R. Mosandl, Catena. 105, 1-10 (2013)

4. P. Kusumo, E. Nursari, J. String. 1, 1, 29-38 (2016)

5. B.B. Ismoyo, M.A. Mardyanto, J. Appl. Environ. Biol. Sci. 7, 3, 59-64 (2017)

6. T.T.N. Nguyen, J. Némery, N. Gratiot, E. Strady, V.Q. Tran, A.T. Nguyen, J. Aime, A. Peyne, Sci. Total Environ. 653, 370-383 (2019)

7. M. Tosic, J.D. Restrepo, S. Lonin, A. Izquierdo, F. Martins, Estuar. Coast. Shelf Sci. 216, 187-203 (2019)

8. Main River Basin Organization Territory Cidanau-Ciujung-Cidurian, Water quality in Cidurian Watershed (Serang, Banten, 2019)

9. Main River Basin Organization Territory Cidanau-Ciujung-Cidurian, Water quality in Cidurian Watershed (Serang, Banten, 2018)

10. Main River Basin Organization Territory Cidanau-Ciujung-Cidurian, Daily Precipitation (2019)

11. Meteorological Climatological and Geophysical Agency, Regulation Number 7/2019 about Preparation and Dissemination of Seasonal Forecast [in Bahasa], Available: http://jdih.bmkg.go.id/vifiles/Penyediaan dan penyebaran prakiraan musim.pdf (2019)

12. A. Uwimana, A.V. Dam, G. Gettel, B. Bigirimana, K. Irvine, Environ. Manage. 60, 3, 496-512 (2017)

13. R.D. Yustika, H. Somura, S.B. Yuwono, B. Arifin, H. Ismono, T. Masunaga, Environ. Monit. Assess. 191, 12, (2019)

14. H.J. Yang, Z.M. Shen, J.P. Zhang, W.H. Wang, J. Environ. Sci. 19, 10, 1193-1198, (2007)

15. P.E. Najjar, A. Kassouf, A. Probst, J.L. Probst, N. Ouaini, C. Daou, D.E. Azzi, Ecol. Indic. 104, 13-23 (2019)

16. A. Barakat, M.E. Baghdadi, J. Rais, B. Aghezzaf, M. Slassi, Int. Soil Water Conserv. Res. 4, 4, 284-292 (2016)

17. T.G. Kazi, M.B. Arain, M.K. Jamali, N. Jalbani, H.I. Afridi, R.A. Sarfraz, J.A. Baiq, A.Q. Shah, Ecotoxicol. Environ. Saf. 72, 2, 301-309 (2009)

18. L. Mena-Rivera, V. Salgado-Silva, C. Benavides-Benavides, J. M. Coto-Campos, T. H.A. Swinscoe, Water. 9, 8 (2017)

19. S. Gandaseca, N. Rosli, J. Ngayop, C. I. Arianto, Am. J. Environ. Sci. 7, 3, 269-275 (2011)

20. S.K. Mokaya, J.M. Mathooko, M. Leichtfried, Afr. J. Ecol. 42, 4, 281-288 (2004)

21. E. Ngoye, J.F. Machiwa, Phys. Chem. Earth. 29, 1161-1166 (2004)

22. Regulation Goverment of Republic Indonesia, Appendix 6 Regulation government of Republic Indonesia No. $22 / 2021$ about Implementation of environmental protection and management [in Bahasa] (2021) 
23. J. Sang-Arun, M. Mihara, Y. Horaguchi, E. Yamaji, Catena. 65, 3, 258-264 (2006)

24. F. Alliaume, W.A.H. Rossing, P. Tittonell, G. Jorge, S. Dogliotti, Agric. Ecosyst. Environ. 183, 127-137 (2014)

25. J.C. Alegre, M. R. Rao, Agric. Ecosyst. Environ. 57, 17-25 (1996) 